\title{
THE ETHICAL AUTHORITY OF THE OLD TESTAMENT: A SURVEY OF APPROACHES. PART II
}

\author{
Christopher J.H. Wright
}

\begin{abstract}
Summary
Current mainline evangelical approaches to Old Testament ethics are represented by the work of Kaiser and Goldingay, for whom the authority of the text has to be applied by the use of derived moral principles. The article then proceeds to critique both dispensationalism, which severely relativizes the Old Testament, and theonomism, which affirms its continuing validity in the civil realm. After brief mention of the approaches of Messianic Judaism and the Jubilee Centre, the author summarizes the assumptions and methodology of his own paradigmatic approach.
\end{abstract}

\section{Introduction}

In the first part of this article, 1 we traced some lines of approach to the ethical use of the Old Testament, from the early Church, through mainline Reformation and Anabaptist writings, to recent critical scholarship. In this part we look at a variety of evangelical approaches to the question, concluding with an outline of my own presuppositions and method in handling the Old Testament for Christian ethics.

\section{Walter Kaiser}

In 1983 a long silence was broken. After more than half a century when no book had been published in English on the subject of Old Testament ethics, two arrived almost simultaneously, their authors quite unaware of each other's work. One, my own Living as the People of God, ${ }^{2}$ sets out a way of understanding the ethical thrust of the Old Testament in general terms and then illustrates its method in several applied areas. It is referred to more fully in the closing section

1Published in TynB 43.1 (1992) 101-20.

${ }^{2}$ C.J.H. Wright, Living as the People of God: The Relevance of Old Testament Ethics (published in USA as An Eye for an Eye: The Place of Old Testament Ethics Today (Downers Grove; Leicester, IVP 1983)). 
of this article. The other, by Walter C. Kaiser, is a much more wide-ranging work. ${ }^{3}$ Kaiser devotes a major first section to a survey of the field itself, its definition, scope and methodological problems, and also a classification of such approaches as were advocated in various scholars' work on biblical ethics in general. After an exegetical survey of the major sections of the law, he organises his material around the central theme of holiness, and proceeds with an exposition of the second table of the decalogue. Finally, he tackles some of the moral difficulties frequently raised by readers of the Old Testament. Kaiser is thus among those who affirm two things about the Old Testament: first, that it can be handled in some systematic, unified way, in spite of its manifest diversity; and second, that it does still hold moral authority for the Christian. On both counts, he finds much current writing on the subject deficient. In a forthcoming article, ${ }^{4}$ he regrets the absence of a sense of coherence or a central principle in writing on Old Testament ethics over the last decade or two, such as characterised the work of Eichrodt. He is well aware of the reasons for this, as expressed by John Barton, 5 but points out that even where a scholar like Barton is willing to see several dominant motifs (such as, conformity to natural order, obedience to divine will, imitation of God), he does not see these as normative or prescriptive. There is, in other words, a marked resistance to a deontological understanding of ethics in treatments of the Old Testament.

In the same article, Kaiser also regrets the effect on ethics of the paradigm shift in Old Testament hermeneutics from concern for author intention to theories of reader response. While there is much to learn and great potential in the newer literary criticism, it can undermine any objective authority the text had in normative ethics. Some practitioners, of course, would say that no such thing exists anyway. There is certainly a shift from attempting some kind of objective, cognitive understanding of the text, to a more subjective, intuitive stance.

${ }^{3}$ Walter C. Kaiser, Jr., Toward Old Testament Ethics (Grand Rapids, Academie 1983).

${ }^{4}$ Walter C. Kaiser, Jr., 'New Approaches to Old Testament Ethics', JETS forthcoming.

${ }^{5}$ See TynB 43.1, $115 \mathrm{f}$. 
More and more, the Bible functions in modern thought as a catalyst suggesting ways in which former communities faced problems, but imposing no categories, no norms, or principles of its ownespecially in an objective, cognitive, or regulative way. ${ }^{6}$

There is little scope here for a revelation-based authority in actual ethical decision making.

Kaiser himself wants to insist on the moral authority of the Old Testament and does so first by calling for a fresh appreciation of the classic division of the law into moral, civil and ceremonial categories. ${ }^{7}$ This ancient scheme, partly perceived by Origen, given clear shape by Calvin, enshrined for Anglicans in Article 7 of the Thirty-Nine Articles of Religion and in the Westminster Confession of Faith, and influential until comparatively recent years, ${ }^{8}$ has fallen into disfavour. The main attack upon it is first that it serves no exegetical purpose, in that it is impossible to make clear divisions into such categories when actually studying Old Testament legal texts, and second that it is foreign to the thought of either Old or New Testament. ${ }^{9}$ However, it could be argued against the first point that it was never intended as an exegetical tool, but as a self-consciously post-biblical hermeneutical means of applying the law in a Christian context. And against the second, Kaiser shows that there is more evidence than one would think for an awareness of some such distinction in the minds of New Testament authors, and indeed that the Old Testament itself prepares the way for it when some of the prophets clearly set up priorities as between the sacrificial and other ritual laws on the one hand and the demands of social justice on the other. In calling for a fresh understanding and application of this way of handling the law, Kaiser is waging a polemic against the 'all-or-nothing' banner of the

6Kaiser, New Approaches', op. cit.

7Walter C. Kaiser, Jr., 'God's Promise Plan and His Gracious Law', JETS 33 (1990) 289-302.

${ }^{8}$ For example, it is the framework of J.N.D. Anderson's discussion of the role of the law for Christian ethics in Morality, Law and Grace (London, Tyndale 1972) 118ff.

${ }^{9} \mathrm{I}$ myself joined in the attack in my earliest wrestling with the task of applying the Old Testament law in 'Ethics and the Old Testament', Third Way 1.9-11 (May-June 1977), articles subsequently reprinted as a booklet, What Does the Lord Require (Nottingham, Shaftesbury Project 1978). 
theonomist/reconstructionist school-that is, either the whole law applies today, or none at all. This position is examined below.

Having reinstated the idea of moral law, Kaiser is keen not to confine it merely to the ten commandments alone, as has often been done. Rather, there is a breadth of moral principles that inform the whole core and meaning of the Torah, and can be drawn on as we seek to apply them to contemporary issues. The law was given, not solely for Israel, but purposely to be of moral relevance to the nations, as the prophets implicitly affirm in their moral evaluation of the nations' behaviour. Kaiser advocates a 'ladder of abstraction' approach, 10 in which the precedents and specifics of Old Testament law are applied to modern situations by way of intermediate moral principles. ${ }^{11}$

In affirming the moral authority of the Old Testament mediated through moral principles derived from the text, Kaiser declines to see Israel as a model for the nations. ${ }^{12}$ This again is because he is resisting the theonomist scheme, particularly as advocated by Greg Bahnsen, in which the expression 'Israel as a model' is used to imply fairly literal and total application of Israel's law, including its penalties in the civil realm. However, in my view, the expression need not be taken in the theonomists' fashion, but can be a useful means of encapsulating the relevance to contemporary ethics of Israel as a total society. It was Israel as a whole community that was to be 'a light to the nations'. It was Israel as a holy nation that was to be a priesthood in the midst of the nations. I believe there are ways that we can use the idea of Israel as a model in applying the Old Testament laws and institutions paradigmatically that avoid the theonomist extreme while preserving their commendable enthusiasm for the abiding ethical relevance of the law. This is the focus of the concluding section of this article.

${ }^{10}$ This is a term and a method also used by Michael Schluter and the Jubilee Centre in its application of biblical materials to social issues, as discussed below.

${ }^{11}$ Kaiser has developed these ideas further than the earlier book Ethics, in Toward Rediscovering the Old Testament (Grand Rapids, Zondervan 1987) 155-66.

${ }^{12}$ Kaiser, 'God's Promise Plan', 296f. 


\section{John Goldingay}

Like Kaiser, Goldingay wishes to affirm the normative authority of the Old Testament in Christian ethics, and also sees the importance of derived or intermediate principles (sometimes called 'middle axioms') as a way of moving from the specifics of the ancient text to the specifics of our modern context. Otherwise the specificness of the Old Testament commands (not to mention its stories and other genres) could induce a kind of ethical paralysis in which one is so aware of the cultural and historical particularity of Israel's laws that one despairs of finding any modern relevance at all, let alone a normative ethic. Against such a negative view, Goldingay points out that the specificity of command to a context need not spell irrelevance to other contexts, since they can be the concrete expression of some general principle which is being applied. There are also human constants that survive cultural discontinuities, as well as the moral consistency of God himself. 13

However, in exploring the necessity of some such procedure, he warns against making the derived principles themselves the locus of authority. It is the text of Scripture itself which remains normative.

If we are concerned with interpreting the Bible itself, it is nevertheless not these hypothetical principles which are normative or canonical. The Bible itself remains the norm. The principles we find in it are part of our interpretation, not the object of our interpretation. They are limited by our blind-spots, and can be the means of missing aspects of the whole message of Scripture or of evading the meaning of the text itself, rather than of serving it.14

This is an important caveat. But it might seem to impale us on a dilemma that on the one hand we have an authoritative text which we cannot directly apply, or which does not actually address the specific moral problem that confronts us, while on the other hand we have derivative moral principles which we can use but which have no intrinsic

${ }^{13}$ These points are made in his chapter 'The Old Testament as a Way of Life', in J. Goldingay, Approaches to Old Testament Interpretation (Leicester, IVP 1981; Updated Edition, Apollos 1990). As well as discussing the problem of the specificness of OT commands, Goldingay tackles the diversity and apparent limitations of OT moral standards.

${ }^{14}$ Goldingay, Approaches, 55. 
authority. It seems to me that we have no alternative but to derive intermediate mechanisms of some kind, which I would prefer to call paradigms (as discussed below), or else the Bible will be ethically gagged and bound. The vital thing, therefore, is that we constantly submit those intermediate means-call them principles, axioms, paradigms or whatever-to revision in the light of the biblical text. Our ethical agenda must be as semper reformanda as our ecclesiology or theology.

In later work, Goldingay examines the importance of historical context in understanding and relating Old Testament laws and narratives. The Bible itself shows how changing contexts called forth different responses and different priorities, and we ought not merely to flatten all that diversity into alleged timeless truths, except in cases where the Bible itself explicitly does so. As a case study in this, Goldingay traces the idea of 'the People of God' through its long historical journey in the Old Testament. He shows how each major period found the people of God in sometimes radically different forms, and facing new challenges and ethical tasks, as they move from the ancestral wandering clan, through theocratic nation, institutional state, afflicted remnant to the post-exilic community of promise. There is continuity and yet obvious diversity as well, and ethical principles drawn from the texts which relate to any of these periods must take into account the interwoven patterns of this historical tapestry. As Goldingay explores this continuity in diversity, he makes it very clear that he sees definite ethical challenges and resources for the Christian church in such a study of just one theme of the Hebrew canon. 15

In the same book, Goldingay puts forward what he calls the 'pastoral strategy' of Deuteronomy. After surveying the book's behavioural values and theological perspectives, he points out that apparent moral tensions between high ethical ideals and some laws which appear less than ethical to us may be resolved by realising that the legislator was concerned both

${ }^{15}$ John Goldingay, Theological Diversity and the Authority of the Old Testament (Grand Rapids, Eerdmans 1987), ch. 3. The insights and structure of this chapter underlie my own 'The People of God and the State in the Old Testament', Themelios 16.1 (1990) 4-10, reprinted as The People of God and the State: An Old Testament Perspective, Grove Ethical Studies no. 77 (Nottingham, Grove Books 1990). 
to set out the highest possible standards of covenant loyalty and behaviour, and yet at the same time to take into account the reality of a sinful, rebellious people and their ambient culture. You have to start where people are-then as now. So the law necessarily made concessions to the facts of sin and of undesirable aspects of historical culture. In noting this, Goldingay takes his cue from the way Jesus handled the divorce controversy. Jesus contrasted the creation ideal with the Mosaic permission. Yet both texts, of course, are part of the same Torah. The Bible itself, therefore, gives us precedent for moral evaluation of some parts in the light of others. 16

The authority of the Old Testament, therefore, is not simply flat and even and equal in every text. While the whole text has its canonical authority, some parts are clearly prescriptive in a way that moves quickly towards application now, while others are more in the nature of 'case-studies' of God's engagement with Israel in situations of greater or lesser obedience to his will.

Thus either the Bible's statements tell us how to live, or (when they do not do this) these actual statements are the model for and the measure of our attempts to state how we are to live. This means we do not ignore the particularity of biblical commands (and apply them to our own day as if they were timeless universals). Nor are we paralysed by their particularity (and thus unable to apply them to our day at all). We rejoice in their particularity because it shows us how the will of God was expressed in their context, and we take them as our paradigm for our own ethical construction. ${ }^{17}$

\section{Dispensationalism}

Dispensationalism traces its roots to J.N. Darby in nineteenth century England, though the premillenialism which it also espouses has a much longer history in the church. Darby found himself frustrated and depressed with the ineffective legalism of Anglican church life at that time. It was ineffective because although it was deeply moralistic in theory, it was abysmally lax in practice. A conversion-type experience liberated him into an experience of the grace of God and a realization of the fulness of the Gospel in Christ. This simultaneously engendered a strong antipathy to 'works', and thence also to

16Ibid., ch. 5.

17Goldingay, Approaches, 55. 
what he perceived to be an over-reliance on the Old Testament in the church's moralizing. ${ }^{18}$

Darby went on to develop a system of biblical understanding which stemmed from his desire to preserve the utter priority of grace over law. The most straightforward way to do this, in a sense, is to separate them altogether. Darby and those who followed his lead 19 did this by arguing that God's dealings with human beings in the course of redemptive history have proceeded by entirely separate dispensations. The precise number of these varies in different schools, but the most fundamental divide is between the dispensation of the law through Moses and that of the present age of grace through Christ. The next most significant will be the millenial earthly reign of Christ. This entails also a complete separation between national Israel and the church. God deals with them differently, and the distinction will be preserved eternally. The moral teaching of the Old Testament law was for the dispensation before Christ alone, and will be the standard again in the millenial age when Christ reigns on earth amongst a converted Jewish nation. But in the age of the church, it has no continuing authority. In the twentieth century, dispensationalism has softened somewhat under the onslaught of so-called covenant theology, and is prepared to recognize that there was grace in the Old Testament also and that salvation was never simply by keeping the law. But its hermeneutical and eschatological system has remained largely intact.

Norman Geisler has provided a helpful statement of a dispensationalist approach to biblical ethics. ${ }^{20} \mathrm{He}$ points out that all Christians, including theonomists, know that Christians are not bound to obey every single law in the Pentateuch since in practice they do not do so and do not urge that others should. 'So even those who claim that Christians

${ }^{18}$ Daniel P. Fuller, Gospel and Law, Contrast or Continuum? The Hermeneutics of Dispensational and Covenant Theology (Grand Rapids, Eerdmans 1980), provides a full account of Darby's pilgrimage and the development of his theological system, followed by an exegetically very thorough examination and critique of the conflict between these opposing systems.

${ }^{19}$ Most influentially, The Schofield Bible.

20Norman L. Geisler, 'Dispensationalism and Ethics', Transformation 6.1 (1989) 7-14. 
are still under the Old Testament Law do not agree that every point is still applicable. The question then is not whether the Mosaic Law is still in force, but how much of it is still binding on Christians' (p. 7). Geisler dismisses the attempt to preserve some part of the law as authoritative by distinguishing between moral, civil and ceremonial categories, arguing that it is not borne out by the New Testament. He cites a list of New Testament passages where the law, as a whole, is regarded as at an end, or that Christians are no longer under it.

According to Paul, with the Law it is either all or nothing at all. So on the one hand, if any of the Law is binding on Christians, then all of it is, but even theonomists cringe at this suggestion. On the other hand, if some of the Mosaic Law does not apply to Christians then none of it does. This is precisely what Paul argues in Galatians. ${ }^{21}$

Geisler is well aware that many Old Testament laws are quoted in the New Testament, along with other uses of the Old Testament there. But he insists that the force of the texts as authoritative law is not carried over. Rather it is the principles that are being applied, sometimes (as in the case of the sabbath or adultery) with significant modifications in the actual law. "There are many similar moral principles in both Old and New Testaments, but it by no means follows that there are the same laws' (p. 10), and certainly not the same penalties. So the Old Testament can provide guidance on social holiness and personal righteousness, but it cannot be applied either theocratically or theonomically today. The law of Moses was never intended as a guide for civil government other than in Old Testament Israel. For that, God has given the unwritten 'natural law' of general revelation.

From this discussion it should also be clear that the law of God (divine revelation) is not the basis for civil law today. God does not presently rule the world's governments by divine law. He desires that they be ruled by civil law based on natural law. Divine law is only for the church. Natural law is for the whole world (Rom. 2:1214) (p. 10).

It is clear from Geisler's discussion in this article that his main target is the theonomists and their insistence on applying the laws of the Old Testament as rigorously as

${ }^{21}$ Geisler, op. cit., 9. See Jas. 2:10; Rom. 6:14; 2 Cor. 3:7, 11; Eph. 2:15; Rom. 10:4; Gal. 3:25; Heb. 7:11, 8:1-2. 
possible (including their penalties) in modern society. $22 \mathrm{He}$ is not denying the relevance of the moral principles exemplified in the Old Testament, but is rejecting its authoritative normativity as law. This is apparent also in his later monograph on Christian ethics, which examines different ethical stances in relation to specific contemporary issues. ${ }^{23}$ There Geisler makes plenty of use of Old Testament texts in framing what he regards as appropriate Christian responses. So in practice he seems to assume the moral relevance of the Old Testament, while theologically declining to accord it normative authority.

In evaluating the dispensationalist approach to Old Testament ethics one can first of all express a positive appreciation for the emphasis on the priority of grace, and for the proper insistence on the centrality of Christ and New Testament fulfilment theology in any Christian interpretation of the Old Testament.

However, in my view the approach is flawed by the theological questionability of the whole dispensationalist scheme, in its severance of the Old from the New Testament redemptively, its denial of the organic spiritual continuity between Israel and the church through the Messiah, and its over-emphasis on the contrast between law and grace. These major distinctives of the theology of dispensationalism appear to demote the Old Testament in a way which makes its ethical use more or less redundant. My impression is that Geisler himself is somewhat exceptional in paying the attention he does to the moral value of the Old Testament. On the whole, the teaching that Old Testament law has no relevance to the present dispensation of the church leads to a kind of practical Marcionism. If the law does not apply until the millenium, the task of finding out what it might mean to us now hardly seems worth the effort. The New Testament offers sufficient moral authority and guidance. It is also my impression that the pre-

22Similarly, theonomist reconstructionism is the main target of the book by $\mathrm{H}$. Wayne House and Thomas Ice, Dominion Theology: Blessing or Curse? (Portland, Multnomah 1988), which includes helpful chapters setting out a dispensational view of the law, esp. chs. 6 $\& 7$.

23Norman L. Geisler, Christian Ethics: Options and Issues (Grand Rapids, Baker 1989; Leicester, IVP 1990). 
millenial eschatology of dispensationalism has a heavily dampening effect on the relevance of the Old Testament to social ethics in the present context. Since the realization of justice and peace will be features of the millenial earthly reign of Christ, they need not be the focus of Christian striving here and now. The primary (if not only) task of the church is evangelism conceived as rescue from a perishing world order. Inevitably this produces a sceptical (sometimes hostile) assessment of the value of Christian involvement in the social, economic, political, educational and legal structures of the present world order. The Old Testament, therefore, with its strong concern for such issues, suffers corresponding neglect. ${ }^{24}$

\section{Theonomism}

At the polar opposite extreme from the dispensationalist demotion of the Old Testament as regards ethical authority lies the theonomist exaltation of it as the permanently valid expression of God's moral will for all societies. The difference could be expressed at its simplest by saying that whereas dispensationalists say that no Old Testament law is morally binding since the coming of Christ, unless specifically endorsed and re-commanded in the New Testament, theonomists argue that all Old Testament laws are perpetually morally binding, unless explicitly abrogated in the New Testament. Theonomists have the same essentially 'all-or-nothing' approach to the law as dispensationalists, except that whereas the latter answer 'Nothing' to the question 'How much of the

${ }^{24}$ Dispensationalists are aware of this criticism, but some argue that such negative pietism is not intrinsic to the dispensational system as such. There is a place for Christian social involvement, but not on the scale, or with the expectations, of the reconstructionist agenda. And for dispensationalists such social involvement is generated via the New Testament and the Great Commission; it does not take its authority or its shaping from the Old Testament. 'Dispensationalists are often accused of being defeatist, just sitting around and waiting for the rapture. It is unfortunate but true that pietism has infected many in the dispensational camp. However, social and cultural impotence is not organic to dispensationalism. The believer is called to a ministry of exposing evil during the night (Eph. 5:11). . . If dispensationalists are not properly involved in issues today, it is not inherent in their theology; rather it is unfaithfulness to their calling.' House and Ice, op. cit., 241, 243. 
Old Testament law is authoritative for Christians?', the theonomists answer 'All—and not just for Christians.'

The theonomist movement has emerged from the Reformed wing of the church, and claims legitimate descent from the teaching of Calvin, the Westminster Confession of Faith, and the Puritans. These claims are strongly resisted by other Reformed scholars who do not accept the validity either of theonomist hermeneutics or of reconstructionist social and political prescriptions, and who say that Calvin and the classic Reformed theologians were by no means theonomist in the modern sense of the word. 25

The movement emphasises the essential unity and continuity of the Old and New Testament and espouses a form of covenant theology. Based on that, they argue that the Mosaic law was given by God as divine revelation not merely for the guidance of Israel, but to provide a perfect model of justice for all societies-ancient and modern. The ceremonial aspects of the law have been fulfilled by Christ and are therefore not binding on Christians-though theonomists argue that they would be were it not for Christ having fulfilled them for us (to this extent theonomists accept differentiation within the law). But all the rest of the law is binding, including its penalties. Laws which older traditions had regarded as 'civil' and distinguished from 'moral' laws are thus included by theonomists in their 'moral and binding' category. Civil authorities in all societies are thus obligated to enforce the laws and penalties of the Mosaic law, and are in a state of sin and rebellion to the extent that they fail to do so. Enforcing the Mosaic law, for theonomists, would include a mandatory death penalty for homosexual offences, rebellious young people, etc. On the penalty for sabbath breaking there are differences of opinion.

'Christian Reconstructionism' is the name chosen by the leaders of the movement who believe that the church should be preparing to reconstruct society and to exercise rightful dominion (another favourite term in theonomic

${ }^{25}$ The most thorough critque of theonomy, which pays attention to its theology, eschatology, ethical agenda and historical roots, comes from a symposium of Reformed 'cousins' from the faculty of Westminster Theological Seminary, William S. Barker and W. Robert Godfrey (eds.), Theonomy: A Reformed Critique (Grand Rapids, Academie 1990). 
vocabulary), to institute a theocratic government which embodies the lordship of Christ in every realm of society. The optimism of this vision easily degenerates into triumphalism. Theologically, it is closely allied to a postmillenialist eschatology which characterizes and shapes reconstructionism as much as premillenialism does for dispensationalism. The founding father of the movement is Rousas Rushdoony, but its growth has largely been due to the theological writings of his disciple, Greg Bahnsen, and the popularizing, and more economics inclined writing and speaking, of Gary North. 26

A helpful starting-point for getting to grips with the theonomist approach to Old Testament ethics is Bahnsen's companion article to Geisler's in Transformation. 27 In it he sets out his case that the general continuity of the moral standards of the Old Testament applies legitimately to the socio-political realm as much as to personal, family or ecclesiastical ethics and that the standing civil laws ${ }^{28}$ of the Old Testament are God's revealed model of perfect social justice for all societies (though he allows for necessary modifications to accommodate changing cultures). He justifies the nonapplicability of those laws which made Israel distinctive symbolically from the nations on the grounds that the New Testament redefines the people of God to include Gentiles as well as Jews, so the old marks of separation are no longer necessary, though their point (separation from ungodliness) is

\footnotetext{
26Rushdoony's most significant work, out of his enormous output, is probably Institutes of Biblical Law (Phillipsburg, Presbyterian and Reformed 1973) which is an exposition of the Decalogue as the blueprint for society. Greg Bahnsen's major contributions have been Theonomy in Christian Ethics (Phillipsburg, Presbyterian and Reformed 1977, 1984) and By This Standard: The Authority of God's Law Today (Tyler, Institute for Christian Economics 1985). An extensive, annotated bibliography of the prolific writings of these and other members of the theonomist, reconstructionist camp is provided by House and Ice, op. cit., 425-44.

27Greg Bahnsen, 'Christ and the Role of Civil Government: The Theonomic Perspective' Part I, Transformation 5.2 (1988) 24-31; Part II, 5.3 (1988) 24-8.

${ }^{28}$ 'Standing law' is Bahnsen's way of distinguishing 'policy' imperatives that were clearly intended to have continuing force over time for classes of people from those which were equally clearly specific to individuals in unique historical contexts (e.g. the command to Abraham to sacrifice Isaac, or to Joshua to invade Canaan).
} 
still a Christian concern. He stresses the importance of Matthew 5:17 and other New Testament texts pointing to the abiding importance of the law, much as dispensationalists point to texts which speak of its 'end'.

In evaluating theonomism's approach to the ethical authority of the Old Testament, one can begin, as with dispensationalism, with some (probably more) words of positive appreciation. I have nothing but applause for theonomists' concern to restore the validity and authority of the Old Testament as an integral part of the whole canon of Christian scripture to the life and witness of the church. There is no doubt that a contributory factor to the social ineffectiveness and moral confusion of the modern church is the practical Marcionism that besets it. Anything which corrects that imbalance is to be welcomed, but one fears that the perceived extremism of the reconstructionist platform may well reinforce rather than reform popular depreciation of the Old Testament.

Secondly, I agree with the theonomists' premise that the Old Testament law was given by God for a purpose that had a wider ethical relevance than solely the shaping of Israel. Nothing less satisfies the assertion of 2 Timothy 3:15ff. that 'All scripture is God-breathed and profitable. . ' I believe that such wider, abiding ethical significance is anticipated and expressed in the Old Testament itself, as we shall see below. Thirdly, it is my view that the Reformed, covenantal understanding of the unity of the testaments and of the fulfilled, redefined nature of Israel in the New Testament, 29 is a more adequate framework for biblical interpretation than dispensationalism, so again I find myself in agreement with a theological premise of theonomy. Fourthly, one appreciates the over-riding desire to see the lordship of Christ recognized and realized in all of life on earth, though I confess to a theological rejection of the postmillenial framework in which reconstructionists expect it and a more subjective rejection of the triumphalist rhetoric with which some reconstructionist writers portray it.

${ }^{29}$ I have explored some of the implcations of this as regards the mission and ethics of Jesus himself in Chris Wright, Knowing Jesus through the Old Testament (London, Marshall-Pickering 1992). 
In spite of sharing some of theonomy's theology and concerns, however, there are various criticisms to be made. 30 First, from the perspective of the sociology of law, it is arguable that theonomists misunderstand the function of law, especially in ancient societies. In biblical ancient Israel and contemporary cultures, law was not always in the form of hard and fast statutes intended to be applied to the letter in formal courts. Judges operated with precedents and paradigms guided by torah which means 'guidance' or 'instruction'. The fabric of Israel's judicial system included local elders, levitical priests, individual circuit judges like Samuel, and after Jehoshaphat's reform, royally appointed judges in fortified towns and an appeal court in Jerusalem ( $2 \mathrm{Ch}$. 19). The emphasis was on the imperative to do justice and act fairly without bribery or favouritism, but much was left to the discretion and judgment of those responsible (Dt. 16:18-20, 17:8-13). 31

Secondly, the theonomists' pre-occupation with enforcing the penalties of Old Testament law for equivalent modern offences attaches too much importance to the literal (and literary) form of the biblical penalties and fails to reckon with two points: (a) that in many cases it is probable that the penalty specified was a maximum penalty which could be reduced at the discretion of the elders or judges handling the matter. This is clear in the law governing the use of the whip as

${ }^{30}$ Two recent books provide extensive and illuminating critiques of theonomic/recostructionist/dominion theology and proposals. House and Ice, op. cit., is from a dispensationalist perspective, and so confronts theonomism head-on at every level-theologically, exegetically, eschatologically, ethically, and socially. Barker and Godfrey, op. cit., is perhaps even more telling in that it attacks theonomy from the same theological perspective on which it is founded. The points I make above are supplementary to the major exegetical and hermeneutical arguments of the latter volume.

${ }^{31}$ On the administration of justice in Israel and the Ancient Near East, and the role of written law within it, cf. Hans Jochen Boecker, Law and the Administration of Justice in the Old Testament and Ancient East, ET, Jeremy Moiser, (London, SPCK 1980) 21-52; Gordon Wenham, 'Law and the legal system in the Old Testament', in B.N. Kaye and G.J. Wenham, Law, Morality and the Bible: A Symposium (Leicester, IVP 1978) 24-52; also Wright, Living as the People of God, pp. 168ff., and idem, God's People in God's Land: Family, Land and Property in the Old Testament (Grand Rapids, Eerdmans; Exeter, Paternoster 1990) 7681. 
punishment (Dt. 25:1-3). Forty strokes was the maximum penalty; the law assumes that fewer than that, at the judges' discretion, would be normal. The fact that in a few specific cases the law prohibits any reduction of penalty (for deliberate murder, Nu. 35:31, idolatry, Dt. 13:8, and false testimony in court, Dt. 19:19-21) suggests that lesser penalties were permissible in other cases. Wenham has suggested that the death penalty for adultery may have been allowed to be commuted to monetary compensation, though would-be adulterers should not count on it (Pr. 6:32-35);32 (b) that what is important about the penal system of Israel's law is the scale of values it reflects rather than the literal prescriptions themselves. Careful study of Israel's penology shows that the range of offences for which the death penalty was applied were to do with the central concerns of protecting the covenant relationship and the family/household unit within which the relationship was preserved and experienced. ${ }^{33}$ The gradation of penalities also shows a clear priority of human life over property and other priorities which challenge the sometimes distorted values of our modern judicial systems. ${ }^{34}$ It is certainly possible to set the scale of moral values reflected in Israel's penalties over against those of our own society and then to observe shortcomings and suggest reforms in order to bring our own system of law and justice more in line with biblical priorities. But this need not take the form of seeking to re-impose Old Testament penalties as they stand. This point seems to be reinforced theologically by the fact that in the New Testament it appears that neither Jesus nor Paul wanted to apply the full weight of the Old Testament penal system, for adultery or for false teaching.

Thirdly, it seems to me that theonomy overstates the importance of the Pentateuchal laws within the overall balance of the Old Testament canon. Now it is obvious that the Torah (as a whole; it should always be remembered that the word

32G. Wenham, op. cit., 35.

33I have explored this more fully in God's People in God's Land. See particularly ch. 3, 'The Family and Israel's Relationship to Yahweh'. Cf. also, 'The Israelite Household and the Decalogue: The Social Background and Significance of Some Commandments', TynB 30 (1979) 101-24.

34See G. Wenham, op. cit., pp. 38ff., and Wright, Living as the People of God, 163-8. 
includes narrative as well as law codes) has a foundational role, and is celebrated in the Psalms and held up against the people of Israel by the prophets. Nevertheless, it seems significant that the historical narratives and prophetic texts (and certainly the Wisdom literature) do not often quote specific laws or call for their implementation, or for specific penalties to be enforced. Not as often, that is, as one would expect if the written, standing law had had quite the central importance in Israel's everyday social affairs as theonomists imply. In fact, if the law was as definitive as theonomists claim, then the narratives portray apparent inconsistenciesthe most notorious being the lack of capital punishment on either Cain or David. It is arguable that a truly prophetic response to the needs of society would not place quite the emphasis that theonomy does on law and punishment. The Old Testament seems aware of the limitations of that approach. 35

Fourthly, the theonomist agenda seems to me oddly selective in what it says modern civil rulers must apply and enforce from Old Testament law and what it says they must not. According to Bahnsen, the realm of the economic marketplace is out of bounds for civil rulers, legislatively or coercively, on the grounds that Old Testament law did not prescribe such intervention.

Outside those areas where God's law prescribes their intervention and application of penal redress, civil rulers are not authorized to legislate or use coercion (e.g. the economic market-place). ${ }^{36}$

But the Pentateuchal law, by any criterion, is deeply concerned about the economic market-place and prescribes a whole raft of mechanisms designed to preserve or restore justice: in relation to the distribution of land, the payment of workers, lending and debt, alleviation of poverty, etc. By whom were these laws and mechanisms administered if not by the civil authorities i.e. the elders? By whom was coercion to be brought to bear on those who tried to evade them? What was Nehemiah, the civil governor, doing when confronting the illegal interest-taking nobles on behalf of the debt-

${ }^{35} \mathrm{Cf}$. my comments on the limitations of the law in Living as the People of God, $17 \mathrm{ff}$.

36Bahnsen, 'Christ and the Role of Civil Government', Part I, 25. 
impoverished farmers (Ne. 5)? To argue that because Old Testament law does not prescribe explicit penalties related to infringement of its economic legislation, therefore modern civil authorities are excluded from any form of intervention in the economic market-place betrays both the inadequacy of theonomism's preoccupation with penalties and also, in my view, its ideological bias towards a free-market economic conservatism.

\section{The Jubilee Centre}

American-style theonomic reconstructionism has not generated a large British following. There is, however, a small movement under the auspices of the Foundation for Christian Reconstruction, begun in 1987, directed by Stephen Perks. It is dedicated to the 'rebuilding of Christian civilisation. . . on the belief that Christ has called His disciples to subject every aspect of life. . .to the authority of God's word'. It shares the same Calvinist Reformed background as American reconstructionists, as well as their theonomic presuppositions and postmillenialist eschatology. It distributes theonomist literature and produces occasional papers and a journal. ${ }^{37}$

More significant in the British scene is the work of the Jubilee Centre in Cambridge, whose work in bringing a biblical perspective to the public arena of social policy, legislation and reform has been recognized both in Parliament and the secular media. The director, Michael Schluter, in collaboration with Roy Clements, has provided the theological and biblical basis for the Centre's various programmes aimed at social reform in Britain 38

Prominent in their theological position is their use of the Old Testament as a normative authority for Christian social ethics. On the basis of New Testament texts such as Matthew 5:17ff. and 2 Timothy 3:16f. they argue that Christians are obliged to search the Old Testament scriptures for ethical guidance and that to confine the relevance of Old

${ }^{37}$ The Foundation for Christian Reconstruction, P.O. Box 1, Whitby, North Yorkshire, England, YO21 1HP.

38Some of their published theological work is referred to below. Much of it still exists as unpublished papers, or as biblical/theological sections in specific, issue-related publications available from 3 Hooper Street, Cambridge, England, CB1 2NZ. 
Testament law to Israel BC is fundamentally misguided. Thus far, they would endorse the stance represented by Kaiser and Goldingay above. However, they are dissatisfied with the proposal that the only way to move from Old Testament text to modern context is by way of derived intermediate principles. The problems they perceive regarding such a 'principles approach' include: How does one determine the 'right' principle when different interpreters derive different principles from the same text or texts? Deriving principles involves a process of abstraction and generalization, the so-called 'ladder of abstraction'. How far 'up the ladder' should one go, what steps are appropriate for descending again into concrete proposals in our own context, and who decides such issues? How do we organize or prioritize our derived principles if they come into conflict with each other? How can we avoid our selection of derived principles being nothing more than a subjective statement of our own bases tangentially linked to the biblical text? Schluter and Clements argue 39 that the only way to avoid these difficulties (or at least to mitigate them) is the holistic approach which regards the whole social system of Israel as a normative model. That is, rather than take isolated laws and attempt to derive moral principles from them, we need to see how individual laws, and whole categories of law, as well as the many social, economic and political institutions of Israel, functioned together. God did not just give arbitrary laws to an otherwise 'neutral' community. He created that community, moulding them out of an unpromising crowd of escaped slaves into a people with distinctive structures of social life in relation to the historical and cultural context in which they lived. It is this total community that was to serve as God's model for the nations. Therefore, any principles we derive from different parts of the model must be integrated

${ }^{39}$ The fullest statement of their position is set out in Reactivating the Extended Family: From Biblical Norms to Public Policy in Britain (Cambridge, Jubilee Centre 1986). In this they give a concise survey of Israel's kinship system and the political and economic structures that went along with it. Then they set out their hermeneutical method of moving from that descriptive work into normative ethics. Finally, they move on to concrete proposals for social reform in Britain that would, in their view, be a starting point for bringing society more into line with the objectives and priorities of the biblical paradigm. I reviewed this work in 'Kin Deep', Third Way, 10.1 (Jan. 1987) 29-32. 
together and consistent with the whole. So, for example, the law banning interest will not be generalized merely into an abstract principle about curtailing greed, but will be understood in relation to Israel's system of land tenure and economic objectives, which in turn are bound up with the importance and role of the extended families, which in turn relates to other features of Israel's judicial and social life. Since so much of Israel's law has to do with creating or restoring a community of justice and compassion in family and societal life, Schluter and Clements have begun to use the term 'Relationism' to describe the social ethical system they wish to build from this biblical base.

By advocating this method, they claim to avoid some of the problems inherent in taking as a starting point for Christian social ethics either a creation mandate or a kingdom of God approach, while preserving the essential truths of each. 40 In their work they endorse and carry further the concept of Israel and its law as a 'paradigm' which I developed in Living as the People of God and refer to further below. It is this overall paradigm, the social shape of Israel in all its dimensions, that acts as a guiding, organizing and prioritizing control on our expression and application of derived principles. Thus, while they share the theonomists' insistence on the relevance and normativity of the Old Testament and its law, they do not share the reconstructionist agenda of enforcing Old Testament laws and penalties through modern legislation. Nevertheless, they are prepared to step out of the world of biblical research into the complex world of actual social policy and legislation. They are prepared, that is, not only to go up the ladder of abstraction, but to come down again with concrete proposals in the public arena. Not everyone will agree with the specifics of all their agenda. Nor do they expect everyone to, still less to compel them to. The point is that there comes a time to move from principles to practice, from questions to answers, from debate to action and the Jubilee Centre at least seeks to do that from a clearly stated hermeneutical approach to the biblical text.

${ }^{40}$ See M. Schluter and R. Clements, 'Jubilee Institutional Norms: A Middle Way between Creation Ethics and Kingdom Ethics as the Basis for Christian Policial Action', EQ 62 (1990) 37-62. 


\section{Messianic Judaism}

Before concluding with an outline of my own approach, it is worth noting the approach of a unique and growing Christian group that is often overlooked, but by its very identity ought to have something to offer on a Christian approach to the Old Testament law-namely Messianic Jews. There have always been Jewish believers, since the days of the New Testament itself of course. Paul accords high theological significance to their existence as the believing remnant of prophecy, in Romans 9-11. Over the centuries the tendency has been that those few Jews who became Christians simply assimilated into the predominantly Gentile churches. There was little other option. However, since the Second World War not only has the number of Jewish believers in Jesus as the Messiah increased dramatically, but also there has emerged the movement known as Messianic Judaism. Messianic Jews are Christian believers who wish to preserve and affirm their identity as Jews and to live and worship in culturally Jewish ways. ${ }^{41}$

One might have thought that Jewish believers committed to preserving their Jewish heritage and choosing to live their lives as far as possible in accordance with the Torah would adopt a more or less theonomic approach to the Hebrew Bible. But this is not the case. As regards the Torah as understood within Orthodox Judaism-including both the written law of the Tanakh (Hebrew Bible, OT) and the oral rabbinic law-the Messianic Jewish position is that a Jewish believer may observe it as a matter of choice. 42 Thus he or she may circumcise children and observe the kashrut (food laws), the sabbath and other festivals, etc. There may be two valid reasons for such observant lifestyle. It may be a matter of ethnic and cultural identity. The Messianic Jew is saying, 'I am

${ }^{41} \mathrm{On}$ the history, background and contemporary significance of Messianic Judaism, see Arthur F. Glasser, 'Messianic Jews - what they represent', Themelios 16.2 (Jan. 1991) 13f.; Walter Riggans, The Covenant with the Jews: What's So Unique About the Jewish People? (Eastbourne, Monarch 1992); David H. Stern, Messianic Jewish Manifesto (Jerusalem, Jewish New Testament Publications 1988).

42Stern, op. cit., describes a spectrum of different answers, from absolute Yes to absolute No, to the question whether Messianic Jews should keep the Torah as understood in Orthodox Judaism, and seems personally to favour the position that it is desirable but not essential. 
a Jewish person, so let me live as one'. Or it may also be a matter of evangelistic integrity, choosing, with Paul (1 Cor. 9:20), to live a Jewish lifestyle within a Jewish context in order to avoid unnecessary offence while witnessing to Jesus. But such laws are not binding. The Messianic Jew may choose to keep them and do so enthusiastically, but he is not obliged to, nor are they in any way linked to salvation.

However, Messianic Judaism argues further that in the light of the New Testament, the very idea of Torah must be redefined. It cannot be confined to (though it still includes) the Old Testament Torah but now encompasses, for the Christian, 'the Torah of the Messiah'43. This includes not only the specific commands of Jesus, but also the total way of obedience and practical holiness to which Christians are called in the New Testament. But the full understanding of New Testament moral teaching actually requires knowledge of Old Testament law which forms the basis for so much of it. Thus, Messianic Judaism agrees that the Old Testament law retains its moral authority for believers, but that it must be set within its total Christian canonical context as part of the new Messianic Torah of the New Covenant. ${ }^{4}$ As regards specific application of Old Testament laws in social ethics, the view seems to be that even though they may not be literally binding, they do provide a primary guide as to how God wants people to live. In other words, when necessary cultural and historical

43Stern, op. cit., 146ff. See also Daniel Juster, Jewish Roots: A Foundation of Biblical Theology for Messianic Judaism (Rockville, Davar 1986) ch. 3.

44Stern is so concerned about the importance of a right Christian understanding of the abiding relevance of the Torah that he devotes a lengthy chapter of his book to it. 'The lack of a correct, clear and relatively complete Messianic Jewish or Gentile Christian theology of the Law is not only a major impediment to Christians' understanding their own faith, but also the greatest barrier to Jewish people's receiving the Gospel' (p. 125). Lamenting the lack of interest in the Law among Christians in general he goes on: 'It means, first, that most Christians have an overly simplistic understanding of what the Law is all about; and, second, that Christianity has almost nothing relevant to say to Jews about one of the three most important issues of their faith. In short, Torah is the great unexplored territory, the terra incognito of Christian theology (p. 126). 
adjustments have been made, the law still retains its moral force in principle by way of concrete example. 45

\section{Conclusion: A Personal Approach}

My own approach to the ethical use of the Old Testament is worked out in greater depth elsewhere. 46 It is proposed to offer here simply a summary of the theological assumptions and hermeneutical methods by which it operates.

a) Assumptions

1. The authority and relevance of the Old Testament for Christians

2 Timothy 3:15-17 is taken as an axiomatic starting-point. This text affirms that the Old Testament law is part of the scriptures which, being God-breathed, are salvifically effective and ethically relevant. The question, therefore, is not whether the Old Testament law has authority and relevance for us as Christians, but how that given authority is to be earthed and that relevance applied.

2. The unity of Scripture

This is not to affirm a flat, Alexandrian-style identity between the Testaments, or to overlook the diversity within the Testaments. Rather, it is my belief that the organic unity and continuity of God's work of revelation and redemption in history, from the call of Abraham to the return of Christ, is a greater reality than, and exercises hermeneutical priority over, the historical discontinuities, covenantal articulations and changing cultural contexts at each stage of its outworking. What God said and did in Old Testament Israel therefore matters to me as a Christian because it is part of the way I have been saved; it is part of my story and part of the story of the salvation of humanity and the creation itself. Similarly, what God required of Israel ethically must speak to me also,

\footnotetext{
45I have not been able to find published material on social ethics from Messianic Jewish sources, but gather the above comment from conversations with some members of the community in Britain. ${ }^{46}$ See C.J.H. Wright, 'The Use of the Bible in Social Ethics', Transformation 1.1 (1984) 11-20; Living as the People of God / An Eye for an Eye; 'The Ethical Relevance of Israel as a Society', Transformation 1.4 (1984) 11-21; God's People in God's Land, op. cit.
} 
because of the moral consistency of God and the continuity of the people of God to whom I belong with them.

3. The priority of grace

The foundation of biblical faith and ethics in both testaments is God's grace and redemptive initiative. So while there is a stronger affinity with 'covenant theology' than dispensationalism (as may have become obvious above!), it is preferable not to speak of a so-called 'covenant of works', even hypothetically.47 The law was never given as a means of salvation (again, even hypothetically), but as a gift of grace to those already redeemed. Thus a rigid separation of law and grace cannot be accepted as a valid way of categorizing the Old and New Testaments, still less the setting of one against the other-except in terms of the specific argumentation of Paul against a distorted view of both.

4. The mission and purpose of Israel

To understand the purpose of the law it is vital to enquire first about the role of Israel in God's purposes. God created and called Israel to fulfil his purpose of blessing the nations. The covenant with Abram (Ge. 12:1-3) has this as its climax, and the phrase is repeated throughout the book of Genesis. Genesis 12 , therefore, has to be read in the light of Genesis 1-11. There was a universal goal to the very existence of Israel. God's covenant commitment to Israel served his commitment to humanity as a whole and therefore what he did in, for and through Israel was ultimately for the benefit of the nations. And furthermore, what God ethically required of Israel served the same purpose. Genesis 18:19 states this clearly, when it links together in one sentence God's election of Abraham, the ethical demand to walk in the way of the Lord by doing righteousness and justice, and the ultimate 'missionary' goalblessing the nations as promised. In other words, the very election of Israel, in all its particularity, not only has a universal missionary goal, but also leads to a clear and distinctive ethical agenda in the world for God's people as part of the condition of that goal being accomplished. Genesis 26:4f. reinforces this by again linking the universal promise of blessing to the specific moral obedience of Abraham, expressed

47I am in agreement here with Kaiser, 'God's Promise Plan', 293-5. 
in terms normally used of the Sinai law even though it had not been given.

5. The function of the law in relation to the mission of Israel Exodus 19:1-6 is a key text at this point. Coming at the hinge between the exodus and the actual giving of the law and making of the covenant, it looks both backwards and forwards. It points to the initiative of God's redemptive grace ('You have seen what I have done. . .') as the essential context for obedience to the law (as the Decalogue also does), and it gives to Israel an identity and role as a priestly and holy people in the midst of 'all the nations' in 'the whole earth' which is God's. Obedience to the covenant law was thus to enable them to be holy-i.e. different, distinctive from the nations. But at the same time, as a priesthood, they were to be teacher, model and mediator for the nations. Keeping the law, then, was not an end in itself for Israel, but related to their very reason for existence-God's concern for the nations. Deuteronomy 4:5-8 sets Israel's social righteousness in the same context-the public stage of the world of nations. If we ask, then, whether the law was given specifically to Israel with particular relevance to them, or was meant to apply to the nations, the answer is, both, but this needs qualification. The law was not explicitly and consciously applied to the nations. But that does not mean it was irrelevant to them. Rather, the law was given to Israel to enable Israel to live as a model, as a light to the nations, such that, in the prophetic vision, the law would 'go forth' to the nations, or they would ' come up' to learn it.

6. Israel and its law as paradigmatic

Given, then, Israel's role in relation to God's purpose for the nations, and given the law's function in relation to that mission of Israel, we can see that the law was designed (along with many other aspects of Israel's historical experience) to mould and shape Israel in certain clearly defined directions, within their own historico-cultural context. That overall social shape, with its legal and institutional structures, ethical norms and values and theological undergirding, thus becomes the model or paradigm intended to have a relevance and application beyond the geographical, historical and cultural borders of 
Israel itself. 48 The particularity of Israel then becomes not a hindrance to universal application, but serves it. The point is that this paradigmatic nature of Israel is not just a hermeneutical tool devised by us restrspectively, but, theologically speaking, was part of God's design in creating and shaping Israel as he did in the first place. When the term 'paradigm' was first used in Living as the People of God the reference was to its function in grammar and language learning. A paradigm verb provides the pattern which you recognize when reading other verbs in any new context, or which you employ in speech or writing to make sure that your own creative use of verbs in other contexts is grammatical. A paradigm can be recognised or applied in widely differing contexts. It enables you to check bad grammar in a piece of speech or writing, and to use good grammar in fresh communication. In the world of science, paradigm can be used in two further ways. It can mean the overall set of assumptions, theories, beliefs and standards in any given field, within which the scientific community carries on its work. Or it can refer to a concrete example of experimental research which provides a model problem-solving in other areas. In some ways Old Testament theology corresponds to the former sense and Israel as a society corresponds to the second. 49 The

48R.E. Clements, 'Christian Ethics and the Old Testament', The Modern Churchman 26 (1984) 22 draws attention to this broad adaptability of Old Testament law which, though he does not use the term 'paradigmatic', is similar in effect to the point I am making. 'What is remarkable in fact is the way in which the Old Testament has provided a system of torâ-instruction, which has proved to be remarkably adaptable to a vast range of human social and political systems. Societies of dramatically different economic, political and cultural types have found within the Old Testament a richly viable source of social and moral teaching'.

${ }^{49}$ I derived this use of paradigm from Vern Poythress, Science and Hermeneutics (Leicester, Apollos 1988) and his fascinating exploration of the potential relevance of the scientific work of Thomas Kuhn to the field of biblical hermeneutics. For further discussion of its helpfulness, see Chris Wright 'The Authority of Scripture in an Age of Relativism: Old Testament Perspectives', in Martyn Eden and David F. Wells (eds.), The Gospel in the Modern World: A Tribute to John Stott (Leicester, Downers Grove, IVP 1991) 42-6. 
first provides a normative framework, the second provides a situational, contextual, specific model. 50

b) Method

1. Distinguish the general categories of Old Testament law This is not just a matter of the classic distinction between moral, civil and ceremonial. Whatever importance and value that retains, it is not adequate to understand the law from an internal Israelite perspective. We need to see the different ways that law functioned in Israelite society, the different kinds of law that operated, and the different patterns of judicial administration. Elsewhere it has been suggested there are five different categories of law: criminal, civil, family, cultic and compassionate. 51 Even within these the distinctions are not always clear-cut, and other sub-categories could be suggested. The point is that in order to make ethical use of the Old Testament one must first step inside it and understand the law from Israel's own social perspective. It is immediately clear that one does not find a separate, textually isolated, category of 'moral law' as such. But what is found is moral motivation and principle expressed or implied in every category one turns to. In order to articulate those moral principles more sharply we need to go further.

2. Analyse the functions of particular laws and institutions When dealing with any particular law, we need to ask how it related to and functioned within the overall social system of Israel. Is it central or peripheral to the dominant themes and social objectives that we find in the rest of the material? Does it reinforce other primary legislation, or is it a modification, or a secondary application? This is where the importance of seeing the overall social shape of Israel really counts. It prevents us from treating every single text with flat equality and enables us to discern those which in Israel itself had priority. As Schluter and Clements rightly say, it is our awareness of this total picture which helps us organize and prioritize any derivative principles we may draw from specific texts. It also helps us avoid the tendency to jump straight from a particular text to

${ }^{50} \mathrm{Cf}$. Vern Poythress, 'Effects of Interpretive Frameworks on the Application of Old Testament Law', in Barker and Godfrey (eds.), op. cit., 103-23.

51 See Wright, Living as the People of God, ch. 7. 
the question, 'How does this apply to modern society?' But such analytical and descriptive work does not come cheap. It calls for an awareness of the breadth of scholarly work being done in the fields of Old Testament economics, politics, sociology, legal history, etc. 52 In this respect, Old Testament ethics has to take into account the whole social world of Israel in the same way that New Testament ethics now looks not just at the biblical text alone but the whole social, economic and political context of the first Christians. 53

3. Define the objective(s) of particular laws

Laws in any society are made for a purpose. They protect interests. They restrict power. They promote social objectives. So, in the light of our understanding of Israelite society, we need to articulate as precisely as possible the objective of any specific law. This can best be done by seeking answers to a number of questions, such as: In Israel's society, whose interests was this law trying to protect? Whose power was it trying to restrict? What kind of behaviour did it encourage or discourage? What kind of state of affairs was it trying to promote or prevent? There are times when the obscurity of some laws defeats even such questioning. But often these questions generate a nuanced understanding of the purpose of Israel's laws which enables a much more targeted application of them when one moves to the final step.

4. Preserve the objective but change the context

Moving from the Old Testament world back to our own, we can ask a parallel set of questions about our context, seeking to identify analogous situations, interests, powers, behaviours, etc. that need to be addressed. Then in that new context we ask how the objectives of Old Testament laws can be achieved, or at least how we can bring our own social objectives to point in the same direction. At this point, of course, we are 'descending the ladder of abstraction' into the realm of specific

52This is not the place for a full bibliography of these enormous fields, but a helpful survey of them is provided by R.E. Clements (ed.), The World of Ancient Israel: Sociological, Anthropological and Political Perspectives (Cambridge, CUP 1989).

53See, e.8., Wayne Meeks, The Moral World of the First Christians (Philadelphia, Westminster 1986; London, SPCK 1987), as well as the various books recently emerging on the economic and political context of the ministry and ethics of Jesus. 
policy and action in our world. But we are doing so, not merely with highly generalized principles, but with much more sharply articulated objectives derived from the paradigm of the society God called Israel to be.

It would seems that such a procedure may help to bridge the gap between an authoritative text which cannot be directly applied and applied principles which have no intrinsic authority. The authority of the Scripture is that which authorizes us to develop our ethical stances, policy choices and decision-making in new contexts not directly addressed by the Bible. The authority of the Old Testament for ethics does not pre-define every choice we have to make. But the more closely and sharply we can perceive and articulate the very particularity of Israel, the more confident we can be in making choices which are 'authorized' - that is, that are legitimate within the contours and limits of the paradigm God has given us. This view also allows for a degree of variety and disagreement among Christians over the details of ethical decisions and social policies. Like the ten commandments themselves, the authority of the Bible sets limits to our behaviour without telling us in specific terms what we must do in every situation. 